\title{
Symptomatic palatal tremor is not limited to the activity of guillain-mollaret triangle: A functional magnetic resonance imaging case study
}

\section{Semptomatik palatal tremor guillain-mollaret üçgeninin aktivitesi ile sınırlı değildir: Bir fonksiyonel manyetik rezonans görüntüleme olgu çalışması}

Hatice Balaban*, Özlem Kayım Yıldız, İbrahim Öztoprak, Ertuğrul Bolayır, Suat Topaktaș

Department of Neurology (Assist. Prof. H. Balaban, MD, Assist. Prof. Ö. K. Yıldız, MD, Prof. E. Bolayır, MD, Prof. S. Topaktaş, MD), and Radiology (Assoc. Prof. İ. Öztoprak, MD), Cumhuriyet University School of Medicine, TR-58140 Sivas

\begin{abstract}
A 57-year-old man was admitted to our clinic because of speech and swallowing disorder for six months. Palatal tremor and left upper extremity myorhythmia appeared on examination. Magnetic resonance imaging showed hypertrophic olivary degeneration, dentate pathology, Wallerian degeneration, and left parietal cystic encephalomalacia. Functional magnetic resonance imaging study of the brain showed prominent activation on the bilateral globus pallidus and thalamus. We suggest that involuntary movements were introduced by the nuclei of the basal ganglia as a result of olivary dysinhibition.
\end{abstract}

Keywords: Palatal tremor, etiology, mechanism, functional imaging

\section{Özet}

Elliyedi yaşında erkek hasta altı aydır olan konuşma ve yutma zorluğu nedeni ile kliniğimize başvurdu. Muayenede ritmik palatal tremor ve solda üst ekstremite kaslarında miyoritmi görüldü. Beyin manyetik rezonans görüntüleme çalışmasında oliver çekirdekte hipertrofik dejenerasyon, dentat çekirdek patolojisi, Wallerian dejenerasyon ve sol parietal hemisferde kistik ensefalomalazik alan görüldü. Fonksiyonel manyetik rezonans görüntülemede her iki globus pallidus ve talamusta belirgin aktivasyon tespit edildi. Bu olgu çalışmasından elde edilen sonuçlar; palatal tremorda görülen istemsiz hareketlerin olivar çekirdeğin disinhibisyonu sonucu bazal çekirdekler tarafindan oluşturulduğunu düşündürmüştür.

Anahtar sözcükler: Palatal tremor, etyoloji, mekanizma, fonksiyonel görüntüleme

Geliş tarihi/Received: February 16, 2012; Kabul tarihi/Accepted: June 19, 2012

*Corresponding author:

Dr. Hatice Balaban, Nöroloji Anabilim Dalı, Cumhuriyet Üniversitesi Tıp Fakültesi, TR-58140 Sivas. E-mail: haticebalaban@yahoo.com

\section{Introduction}

Palatal tremor (PT), also called palatal myoclonus, is a hyperkinetic movement disorder characterized by rhythmic, involuntary contractions of the soft palate and may be associated with synchronous movements of the adjacent structures, including the pharynx, larynx, face, arm, and diaphragm. PT can be either essential (EPT) or symptomatic (SPT). There is no known origin, and magnetic resonance imaging (MRI) is normal in EPT. This form is clinically characterized by the occurrence of ear clicks. SPT is usually the result of a lesion in the triangle of Guillain and Mollaret and is associated with hypertrophic olivary degeneration (HOD). HOD can be seen on MRI as enlargement 
and increased signal on $\mathrm{T} 2$ and proton density-weighted images of the inferior olivary nucleus (ION). Stroke, demyelinating lesions, tumor, and trauma are the most common causes of SPT [1-4]. The pathological mechanism of the rhythmic contractions remains unexplained. Hyper-activation of the putamen and inferior olivary nucleus in functional magnetic resonance imaging (fMRI) has been reported in idiopathic form. However, fMRI study of the basal nucleus in the symptomatic forms has not been previously reported.

\section{Case report}

A 57-year-old right handed man was admitted to our service because of a speech and swallowing disorder for six months. He reported an episode of ischemic stroke four years ago. His past medical history was remarkable for hyperthyroidism. On admission, his general physical examination findings were normal except for low body weight. The patient weighted $58 \mathrm{~kg}$ and was $176 \mathrm{~cm}$ tall. He had no fever; his pulse was 100 beats per minute and regular; blood pressure was $120 / 70 \mathrm{~mm} \mathrm{Hg}$, and his respiratory rate was 20 breaths/min. A neurological examination revealed dysarthria and dysphonia. Pharyngeal reflex was normal. Rhythmic spontaneous tremor was observed in the left soft palate, pharynx, tongue, and left part of the face and arm. All deep tendon reflexes were mildly increased in bilateral upper and lower extremities with flexor plantar response on both sides. Slight weakness was found on the proximal part of the left upper extremity. The other neurological examination findings were also normal. The serum hormone analysis demonstrated hyperthyroidism. There were no other abnormal findings in other routine laboratory data, including urine analysis, serum levels of glucose, electrolytes, liver enzymes, urea, creatinine, protein, magnesium, phosphate, vitamin B12, folate, and thyroid antibodies. Tests for antinuclear antibody, complements 3 and 4, and rheumatoid factor and C-reactive protein levels were either negative or within normal limits. Serological tests were negative for HIV, syphilis, and hepatitis B and C viruses. The motor and sensory nerve conduction velocities of the bilateral upper and lower extremities were within normal limits. Concentric needle electromyography of the left abductor digiti minimi, biceps brachii, deltoid sternocleidomastoid, and left part of the orbicularis oris muscles revealed myorhytmia. MRI of the brain revealed large cystic encephalomalacia at the left temporal and parietal lobe (Figure 1).

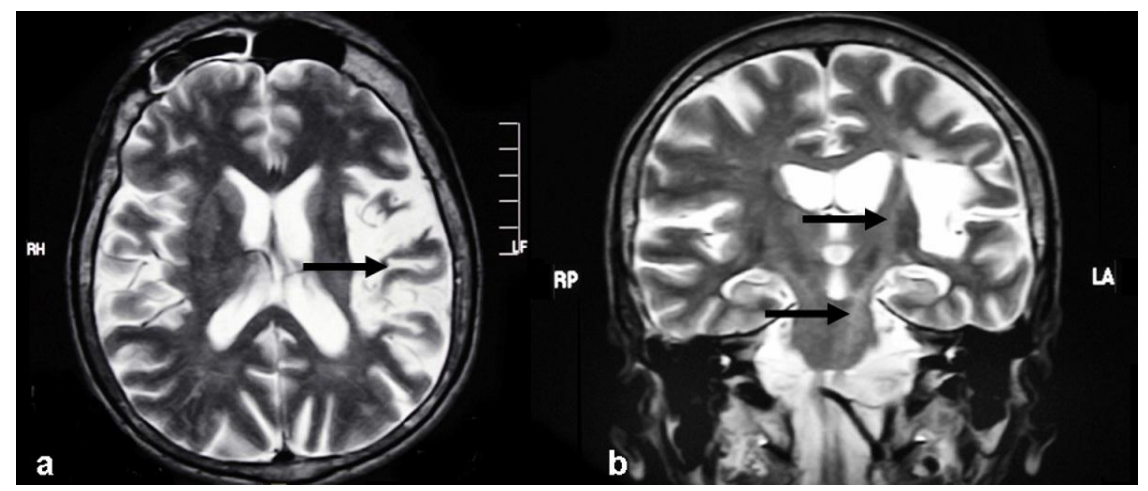

Figure 1a and b. Large cystic encephalomalacia at the left temporal and parietal lobe. $1 \mathrm{~b}$. Hyper intensity on $\mathrm{T} 2$ weighted images in the left part of the mesencephalon and pons due to Wallerian degeneration on MRI.

Hypo intensity on T1-weighted images and hyper intensity on T2-weighted images in the left part of the mesencephalon and pons due to Wallerian degeneration were seen on MRI (Figure 2). Another high intensity lesion appeared on a T2-weighted image, which showed hypertrophy on the right part of the bulbus. This lesion was interpreted as olivary hypertrophy. In addition, two milimeters of cystic degeneration was also seen in the left dentate nucleus (Figure 3). 


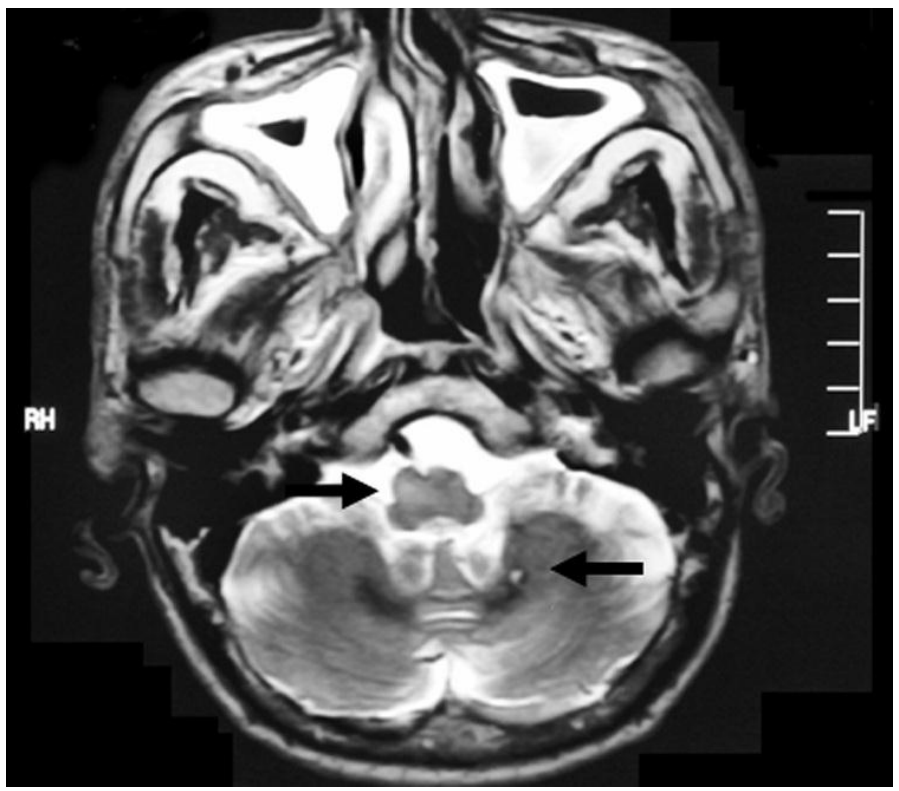

Figure 2. High intensity lesion on a T2 weighted image and hypertrophy at the right part of the bulbus consistent with olivary hypertrophy and two milimeters of cystic degeneration in the left dentate nucleus.

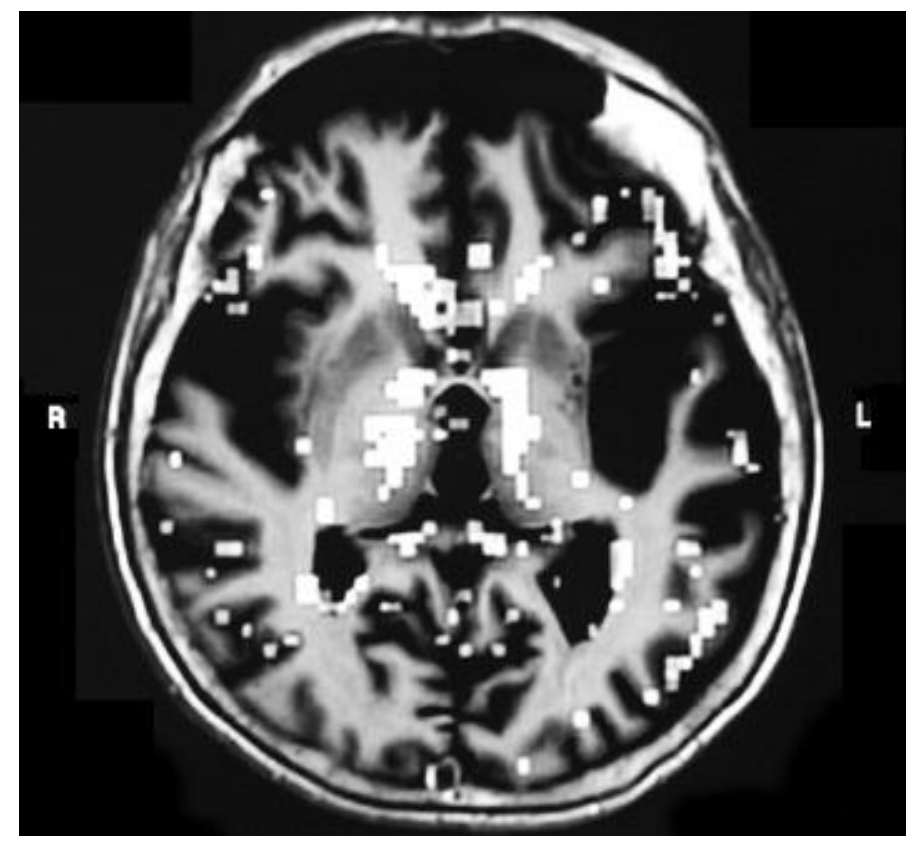

Figure 3. Activations in the bilateral globus pallidus, thalamus and inferiomedial frontal, left parietooccipital cortex on fMRI.

The fMRI of the basal ganglia study was performed after a brain MRI. Prominent activations within regions corresponded to the basal ganglia bilaterally and closely resembled the anatomic boundaries of the globus pallidus and thalamus were seen on fMRI. Additional neuronal activations were present in the inferiomedial frontal, left parietooccipital cortex (Figure 3). These activations were reproduced in the second functional imaging at day 10. no significant activation was detected in other basal ganglia nuclei. 


\section{Discussion}

PT has intrigued scientists since the 19th century [1]. The anatomical correlations, including the dentatorubral and olivary connections, were described by Guillain and Mollaret in 1931 [2]. Unilateral or bilateral rhythmic, involuntary, and permanent contraction of the soft palate occurred during neurological examination. Involuntary soft palate movement could be associated with synchronous movements of the pharynx, larynx, face, arm, and diaphragm. Stroke is the most common cause of SPT. Trauma, demyelinating lesions, and degenerative diseases are the other diseases in etiology [3-8]. HOD could be seen on MR images as enlargement of the inferior olivary nucleus with increased signal on T2 and proton density-weighted images. In contrast to SPT, EPT has no accompanying MR findings compatible with HOD [9-11]. MR characteristics of the dentate-rubro-olivary pathway in PT cases have been well defined [12-14]. HOD usually occurs ipsilateral to the lesion when the lesion is in the brain stem, or contralateral to the lesion when the lesion is in the cerebellum as identified on MR images [1, 15]. An interesting feature in our case is that we saw HOD and Wallerian degeneration on different sides. HOD may be due to dentate nucleus pathology of the cerebellum on opposite sides. The relationship between the inferior olive and SPT is well known. However, it is still a controversial neurological issue. The literature reports that $\mathrm{IOH}$ is a form of trans-synaptic degeneration that occurs in cases of lesion in the dento-rubroolivary pathway. Because IOH is associated with hypertrophy rather than atrophy, this type of degeneration is unique. Nishie et al. [16] reported that the inferior olive or dentate-olivary pathways may function as an inhibitor of the normal generation of SPT. Rhythmic tremor appear from a generator in the brainstem or another cerebral location when this anatomic pathway of the brainstem is disturbed. This holds true only for patients with SPT because there are no autopsy findings reported in EPT. There are few functional MRI studies of voluntary PT in the literature. Nitschke et al. [17] found hyperactivation of the inferior olive on fMRI in a patient with voluntary PT. Voluntary PT obviously differs from the symptomatic and essential forms. Thus, we investigated patients with SPT whose disease was different from the voluntary PT. There is no information about the functional imaging of the basal nucleus region of the brain in symptomatic form. Haller et al. [4] reported prominent activation of the putamen on fMRI in a patient with PT. However, their patient had an essential form of the disease. To our knowledge, our case is the first in the literature with prominent activation of the basal ganglia in the symptomatic group.

This case study revealed bilateral prominent pallidal and thalamic activation on fMRI associated with SPT. This result implies that basal ganglia play an important role in the generation of the involuntary movements in SPT. We suggest that nuclei of the basal ganglia are activated as a result of dysinhibition related hypertrophic olivary degeneration. A limitation of the present study is that it is only a single case description. Large series are necessary to confirm our findings.

\section{References}

1. Goyal M, Versnick E, Tuite P, Cyr JS, Kucharczyk W, Montanera W, Willinsky R, Mikulis D. Hypertrophic olivary degeneration: metaanalysis of the temporal evolution of MR findings. Am J Neuroradiol 2000; 21: 1073-7.

2. Choh NA, Choh SA, Jehangir M. Hypertrophic olivary degeneration: the forgotten triangle of Guillain and Mollaret. Neurol India 2009; 57: 507-9.

3. Hommet CD, De Toffol B, Cottier JP, Autret A. Bilateral olivary hypertrophy and palatal myoclonus. Surg Neurol 1998; 49: 215-6.

4. Haller S, Winkler DT, Gobbi C, Lyrer P, Wetzel SG, Steck AJ. Prominent activation of the putamen during essential palatal tremor: A functional MR imaging case study. Am J Neuroradiol 2006; 27: 1272-4.

5. Okamoto Y, Mitsuyama H, Jonosono M, Hirata K, Arimura K, Osame M, Nakagawa M. Autosomal dominant palatal myoclonus and spinal cord atrophy. $\mathbf{J}$ 
Neurol Sci 2002; 195: 71-6.

6. Suyama N, Kobayashi S, Isino H, Iijima M, Imaoka K. Progressive supranuclear palsy with palatal myoclonus. Acta Neuropathol 1997; 94: 290-3.

7. Birbamer G, Gerstenbrand F, Aichner F, Buchberger W, Chemelli A, Langmayr J, Lo Presti R, Pollicino P, Bramanti P. MR-imaging of post-traumatic olivary hypertrophy. Funct Neurol 1994; 9: 183-7.

8. Bansal B, Singh P, Shukla R. Palatal myoclonus following head injury: letter to the editor. Neurol India 2002; 50: 222-3.

9. Hirono N, Kameyama M, Kobayashi Y, Udaka F, Mezaki T, Abe K, Nishitani N. MR demonstration of a unilateral olivary hypertrophy caused by pontine tegmental hematoma. Neuroradiology 1990; 32: 340-2.

10. Salamon-Murayama N, Russell EJ, Rabin BM. Diagnosis please. Case 17: hypertrophic olivary degeneration secondary to pontine hemorrhage. Radiology 1999; 213: 814-7.

11. Deuschl G, Wilms H. Clinical spectrum and physiology of palatal tremor. Mov Disord 2002; 17 Suppl 2: S63-6.

12. Alstadhaug KB. Oculopalatal and cerebellar limb tremor due to hypertrophic olivary degeneration. Eur J Neurol 2007; 14: e6-7.

13. Tsui EY, Cheung YK, Mok CK, Yuen MK, Chan JH. Hypertrophic olivary degeneration following surgical excision of brainstem cavernous hemangioma: a case report. Clin Imaging 1999; 23: 215-7.

14. Kim SJ, Lee JH, Suh DC. Cerebellar MR changes in patients with olivary hypertrophic degeneration. Am J Neuroradiol 1994; 15: 1715-9.

15. Rabin BM, Hebel DJ, Salamon-Murayama N, Russell EJ. Distal neuronal degeneration caused by intracranial lesions. AJR Am J Roentgenol 1998; 171: 95-102.

16. Nishie M, Yoshida Y, Hirata Y, Matsunaga M. Generation of symptomatic palatal tremor is not correlated with inferior olivary hypertrophy. Brain 2002; 125: 1348-57.

17. Nitschke MF, Krüger G, Bruhn H, Klein C, Gehrking E, Wessel K, Frahm J, Vieregge P. Voluntary palatal tremor is associated with hyperactivation of the inferior olive: a functional magnetic resonance imaging study. Mov Disord 2001; 16: $1193-5$. 